\title{
ПОИСК НОВЫХ ПРОТИВОВИРУСНЫХ ВЕЩЕСТВ НА ОСНОВЕ 2-ТИОУРАЦИЛА И АДАМАНТАНА
}

\author{
А.Р. Титова', Е.С. Титова ${ }^{1,2}$ \\ ${ }^{1}$ Педиатрический факультет, Волгоградский государственный медицинский университет, \\ 400131, Волгоград, Российская Федерация, пл. Павших Борцов, 1 \\ ${ }^{2}$ Кафедра органической химии, Волгоградский государственный технический \\ университет, 400005, Российская Федерация, Волгоград, проспект Ленина, 28.
}

DOI: 10.19163/MedChemRussia2021-2021-510

E-mail: titova051@rambler.ru

В данный момент ведется интенсивный поиск и разработка новых, обладающих низкой токсичностью, лекарственных средств с целью осуществления профилактики и лечения вирусных инфекций. Известно, что соединения на основе 2-тиопиримидина ингибируют обратную транскриптазу ВИЧ-1, таким образом их можно использовать для лечения ВИЧ-инфекций, также они обладают противомикробной активностью [1]. Вещества, принадлежащие к ряду адамантана, например римантадин, применяют для лечения заболеваний, возникающих под действием вируса гриппа А, они обладают также антипаркинсонической, антибактериальной и другими видами биологической активности. Зачастую введение фрагмента адамантана в структуру лекарственных препаратов приводит к ощутимому повышению терапевтического эффекта [2]. Тем не менее, их использование ограничивается наличием большого количества побочных эффектов и возникновением резистентности у вирусов и бактерий.

Таким образом, представляется интересным изучение противовирусной активности соединений, сочетающих в своем строении фрагменты адамантана и 2-тиоурацила. В качестве таких объектов предлагаются к рассмотрению синтезированные нами в водно-диоксановой среде при $50^{\circ} \mathrm{C}$ в течении 1 часа из S-натриевой соли 2-тиоурацила1,3-ди-[4-(6-метилпиримидин4(3Н)-он-2-сульфанил)бензил]адамантан, 1,3-ди-[4-(6-метилпиримидин4(3Н)-он-2-сульфанил)бензил]-5-(4-бромбензил)адамантан $\quad$ и 1,3-ди-[4(6-метилпиримидин-4(3Н)-он-2-сульфанил)бензил]-5-(4-гидроксибензил) адамантан [3].

\section{Литература}

[1]. Synthesis of novel 2-(substituted amino)alkylthiopyrimidin-4(3H)-ones as potential antimicrobial agents / M.I. Attia, A.A. El-Emam, A.A. Al-Turkistani [et al.] // Molecules. 2014. - №19. - P. 279-290.

[2]. Морозов И.С., Петров В.И., Сергеева С.А. Фармакология адамантанов/ Волгоград: Волгоградская мед. Академия - 2001. - 320 с.

[3]. Титова Е.С. S- и О-анионы, генерируемые из 6-метил-2-тио-, 2-алкил(аралкил) тиоурацилов, в синтезе S-моно- и S-, О-диалкил-, бензилпроизводных: Дис. канд. хим. наук: 02.00.03/Титова Евгения Станиславовна-Волгоград: 2005.-154 с. 